\title{
JÁSZBERÉNYI Melinda
}

\section{A MOBILITÁS MENEDZSELÉSE VÁROSI KÖRNYEZETBEN}

A gépkocsihasználat környezeti és társadalmi költségeinek, mint például a torlódás, zaj, légszennyezettség, emelkedése és az energiaforrások kimerülése feltehetôen hatással lesz a gépkocsik számának és használatának jövốbeli alakulására. Sok nagyvárosban ezek az említett negatív következmények már tények és olyan sürgốs problémák, amelyeket meg kell oldani. A fenntartható fejlódés fogalmának elterjedése magával hozta a fenntartható mobilitás fogalmának vizsgálatát is. Az utazási (és hozzátehetjük: az áruszállítási) teljesítmények növekedési üteme az utóbbi évtizedekben világszerte gyorsabb a gazdaságok növekedési üteménél, olyannyira, hogy az igények kielégítése a jelenlegi technikai szinten már szinte megoldhatatlannak túnik, a nem túlságosan távoli jövóben pedig már-már megoldhatatlan feladattá válik. Mindezek ellenére a fenntartható mobilitás, pontosabban: a környezetileg, társadalmilag és gazdaságilag fenntartható közlekedés alaposabb, intenzívebb vizsgálata nemzetközi szakmai, tudományos körökben csupán az 1990-es években kezdódött el.

Kulcsszavak: mobilitás, fenntarthatóság, közlekedésikereslet-menedzsment

Az elsősorban városi környezetben, lakott területeken jelentkezô egészségügyi és környezeti hatások mellett egyre fontosabbá válik a közlekedés energiafelhasználásának mérséklése, az üvegházhatású gázok kibocsátásának csökkentése. A közlekedés ma az egyetlen ágazat, amely folyamatosan növeli teljesítményét és ezzel együtt energiafelhasználását is. Közép- és hosszabb távon a közlekedésnek is hozzá kell járulnia a környezet védelmét célzó erófeszítésekhez, csökkentenie kell $\mathrm{CO}_{2}$-kibocsátását, összhangban a nemzetközi kötelezettségekkel, a Kiotói Jegyzókönyvben foglaltakkal és az EU e téren tett vállalásaival.

A jövő tudatos formálásának egyik eszköze lehet a mobilitás menedzselése. E módszer akkor használható, ha elemezni tudjuk a háztartások utazásait, miképp befolyásolják a közlekedésikereslet-menedzsment (travel demand management, TDM) eszközei a közlekedési opciókat időben, költségben és kényelemben. A megoldásra való törekvés számos intézkedési javaslatot eredményezett. A különbözó, a közlekedési problémákat csökkentô vagy megszüntetô intézkedések potenciális hatékonysága és sikere a nagyvárosi területeken nagyban függ attól, hogy az emberek miképpen reagálnak ezekre.

\section{A mobilitásmenedzselés elvi alapjai}

Az egyik - mondhatni hagyományos - módszer az, amely szerint a nagyvárosi térségekben a légszennyezés és a torlódások csökkentését a közlekedés fejlesztésével igyekeznek megoldani. Ezek közül számos, így például a közúti infrastruktúra kapacitásának növelése, a gépjármú-technológia fejlesztése és a sebességkorlátozás nem követeli meg a gépkocsik használatának csökkentését, legalábbis rövid távon biztosan nem. A másik módszer a keresletet csökkentó intézkedések köre, amelyeket elsósorban a nagyvárosi térségekben kell bevezetni.

A széles körben javasolt, autóhasználatot csökkentó intézkedések között nem csak jogi vagy gazdasági eszközökre kell gondolnunk. Az autóvezetók kedvét szeghetik az olyan intézkedések, amelyek a vezetést nem teszik vonzóvá. Az alternatív közlekedési módok fejlesztése - mint a tömegközlekedés, kerékpározás, gyaloglás -, az otthonok, munkahelyek, vásárlási és szabadidős létesítmények relatív helyének változtatása a távolságok csökkentése érdekében, mind-mind a mobilitási menedzsment feladatai közé tartoznak. Ezek az intézkedések különböznek egymástól hatékonysá- 
gukban, költségükben, technikai kivitelezésükben és politikai megvalósíthatóságukban. Vlek, C. és Michon, J. már 1992-ben az intézkedések 1. táblázatban látható kategorizálását javasolta (a korlátozás erôsségében rendezve, csökkenő sorrendben):
A TDM-intézkedések különbözó csoportosítása ígéretes a fogalomalkotás és a magatartás változása (vagy annak hiánya) lehetséges okainak megértése szempontjából, és ezt érdemes követni a magatartási hatások mély, empirikus elemzéséhez. Az első szükséges lépés annak

\section{Autóhasználatot csökkentő intézkedések}

\begin{tabular}{|c|c|}
\hline \multirow[t]{5}{*}{ Magas } & - fizikai változtatások: autóforgalom kizárása, alternatív módok biztosítása \\
\hline & - jogi szabályozás \\
\hline & - gazdasági ösztönzés \\
\hline & - információ, oktatás és meggyőzés \\
\hline & - szocializáció és szociális modellezés a szociális normák megváltoztatásának céljával \\
\hline Alacsony & - intézményi és szervezeti változások: rugalmas munkaidő, telekommunikáció \\
\hline
\end{tabular}

Forrás: (Vlek - Michon, 1992)

A korlátozóbb intézkedéseknek a hasznok mértékét meghaladó negatív mellékhatásai lehetnek, míg a kevésbé korlátozó stratégiák rossz gépkocsihasználatot determináló tényezók feltételezésein alapulhatnak. A TDM-intézkedéseket a szerint is lehet csoportosítani, hogy a gépkocsi használatától kedvetlenít el (push intézkedések), vagy az alternatív módok használatára buzdít (pull intézkedések) (Steg - Vlek, 1997). A 2. táblázat több példát mutat be a push-tól a pull-ig tartó intézkedésekre. meghatározása, hogy a TDM-intézkedések miképpen hatnak az emberek közlekedési választására a költség, az idő és a kényelem szempontjából, azután lehet megállapítani, hogyan reagálnak ezekre a változásokra.

Fontos kérdés az, hogy miképpen és hogyan változik valójában az utazás. Egyre nyilvánvalóbb, hogy $a z$ utazások az emberek választásainak eredménye, ezért hiba lenne, hogy ha csak egy intézkedésre koncentrálnának. Egy alternatív módszer (Gärling, 2002) az utazási választásra úgy tekint, mint a változásokhoz való alkalmazkodásra, amikor is az emberek különbözô választási lehetôségeket próbálnak ki.

Push és pull TDM-intézkedések

\begin{tabular}{|c|c|c|}
\hline \multirow[t]{13}{*}{ PUSH } & \multirow{13}{*}{$\uparrow$} & - Az autók és az üzemanyag megadóztatása \\
\hline & & - Autók kitiltása a belvárosokból \\
\hline & & - Útdíj \\
\hline & & - A parkolás kontrollálása \\
\hline & & - Sebességkorlátozás \\
\hline & & - Új közúti beruházások csökkentése vagy megszüntetése \\
\hline & & - Távmunka \\
\hline & & - Területi tervezés az utazási távolságok csökkentése érdekében \\
\hline & & - Közlekedési menedzsment a módok és jármúvek közötti tér újraosztásával (pl. buszsáv) \\
\hline & & - $\mathrm{P}+\mathrm{R}$ \\
\hline & & - A tömegközlekedés fejlesztése (pl. gyakoriság, komfort, információnyújtás) \\
\hline & & - A gyaloglás és kerékpározás infrastruktúrájának fejlesztése \\
\hline & & - Kampány a vezetés negatív hatásairól \\
\hline PULL & & - Szociális modellezés \\
\hline
\end{tabular}

Forrás: (Steg - Vlek, 1997) 
Az általános cél annak megértése, hogy a TDMintézkedések miképpen és hogyan hatnak a gépkocsi használatára. Gärling, T. (2002) egy elvi keretszerkezetet javasol, amely segítene a TDM-intézkedések hatásainak értékelésében. Az elvi keretszerkezet áttekintő képe az 1. ábrán látható.

A közlekedési opciókat úgy értelmezik, mint az utazási láncok jellemzóinek (okok, indulási és érkezési idôk, utazási idő, pénzügyi költségek, bizonytalanság és kényelem) kombinációját. Általánosan elfogadott, hogy inkább az utazási láncok, és nem az utazások a választási lehetôségek (Axhausen - Gärling, 1992). A szerzők véleménye szerint az utazási láncokat szubjektíven kellene definiálni, figyelembe véve azt, hogy az emberek mit észlelnek utazási láncként vagy utazási választásként. Az ilyen definíció kifejezi a választási lehetőségek kialakításának folyamatát.

A választási tényezôket két csoportba lehet sorolni:

a) a háztartások utazási választását jellemző tulajdonságok csoportjai, illetve b) a célok és végrehajtási szándékok, amelyeket a háztartások alakítanak ki, válaszolva az utazás költségének, idejének és kényelmének értékeléseire.

A választási lehetőségeket közvetlenebbül befolyásolhatják a negatív környezeti hatásokkal kapcsolatos információk. A tájékoztatás a költségek lehetséges lefaragásán keresztül az autóhasználat kívánt csökkentésének a formáját is felveheti. Az ilyen célok és a végrehajtási szándékok részben meghatározottak az olyan különbözô, relatíve állandó tényezók által, mint például a jövedelem, a családi szerkezet, a munka, a tevékenységi és az utazási szokások, attitúd (pl. környezetvédelem).

A háztartások sokféle terv közül választhatnak, mint például az otthonmaradás, az elektronikus kommunikációs eszközök használata, car pooling, az utazási láncok jellemzóinek (mód, indulási idô) megváltoztatása. Ezen kívül hosszú távú stratégiai változtatást is megfontolhatnak, mint például az elköltözés, az autó

A javasolt elvi keretszerkezet

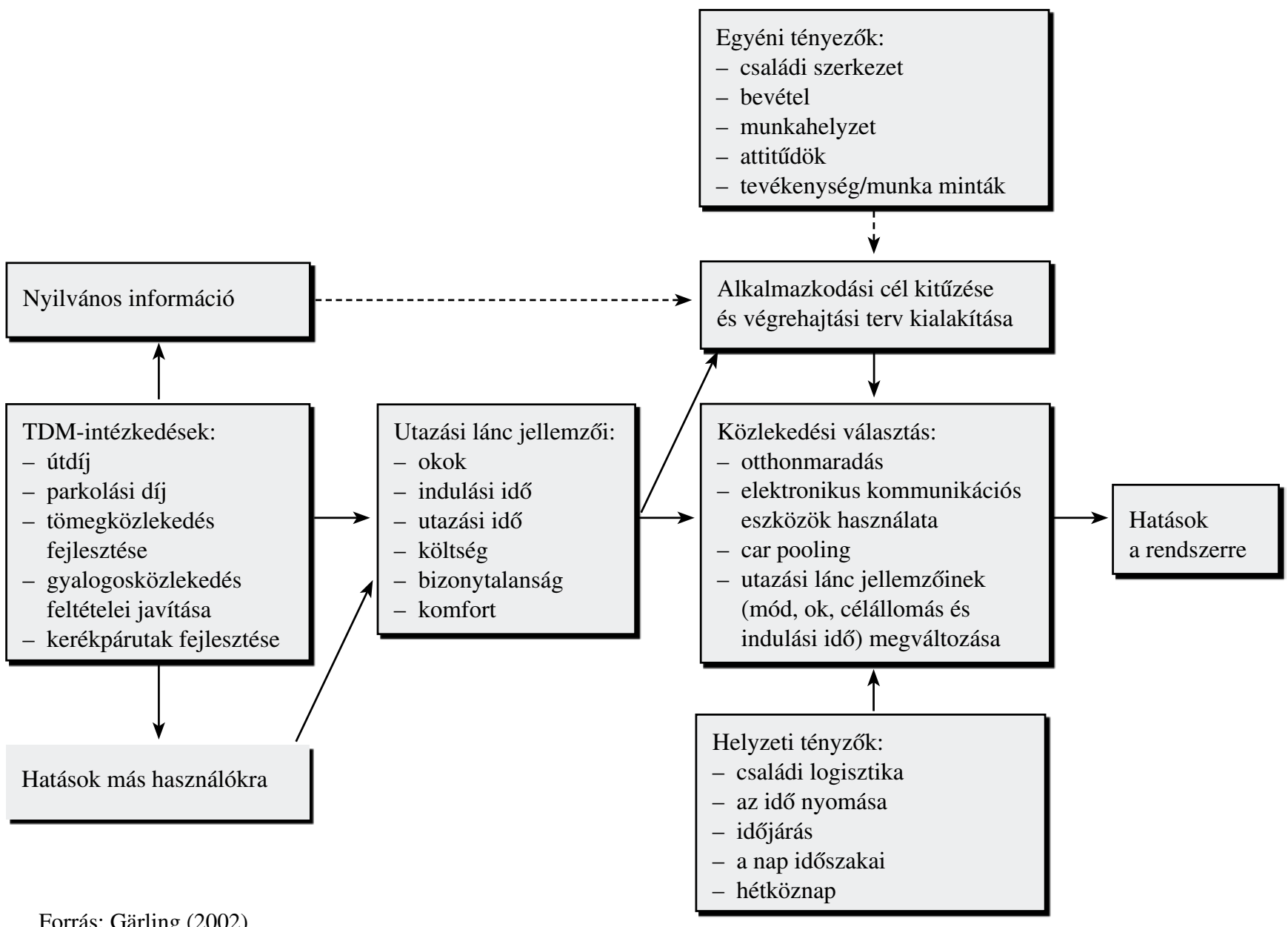


eladása, a munkahely vagy a munkaidő megváltoztatása. A lehetőségek közötti választás úgy történik, hogy kezdve a legkisebb költségú lehetôségekkel, kipróbálnak néhányat, majd döntenek.

Az 1. ábrán látható keretrendszerben azt feltételezik, hogy a TDM-intézkedések hatással vannak az utazási lánc jellemzőire. Ezek a változások mind közvetlenül, mind közvetetten hatnak az emberek utazási választására, és közvetlenül a jellemzók változásához igazított célok kitűzésére. Például, ha bevezetik az útdíjat, akkor az emberek utazási költségeik növekedését tapasztalják. Az egyéni tényezók, mint például a jövedelem, feltételezhetően befolyásolják, hogy kialakul-e a költségcsökkentési cél. Amennyiben igen, a megemelkedett költséget csökkenteni akaró emberben megjelenik (megjelenhet) az utazás egyéb paramétereit változtató szándék. A TDMmel foglalkozó szakértốk szerint a különböző TDMintézkedések megváltoztatják az utazási lánc jellemzőit.

Az irányítási modell alapján a negatív visszacsatolás koncepciója az, amelyik minimalizálja a cél-vagy referenciaértéktól való eltérést, az elvi keretrendszert hasznosan finomítja. Az emberek érzékelik a jelenlegi helyzetet, és értékelik azt a cél- vagy referenciaértékhez képest. Ha van eltérés a kettó között, akkor cselekednek, ezáltal csökkentve a különbséget.

2. ábra

\section{A kontrollelmélet egy alkalmazása az autóhasználat csökkentésére}

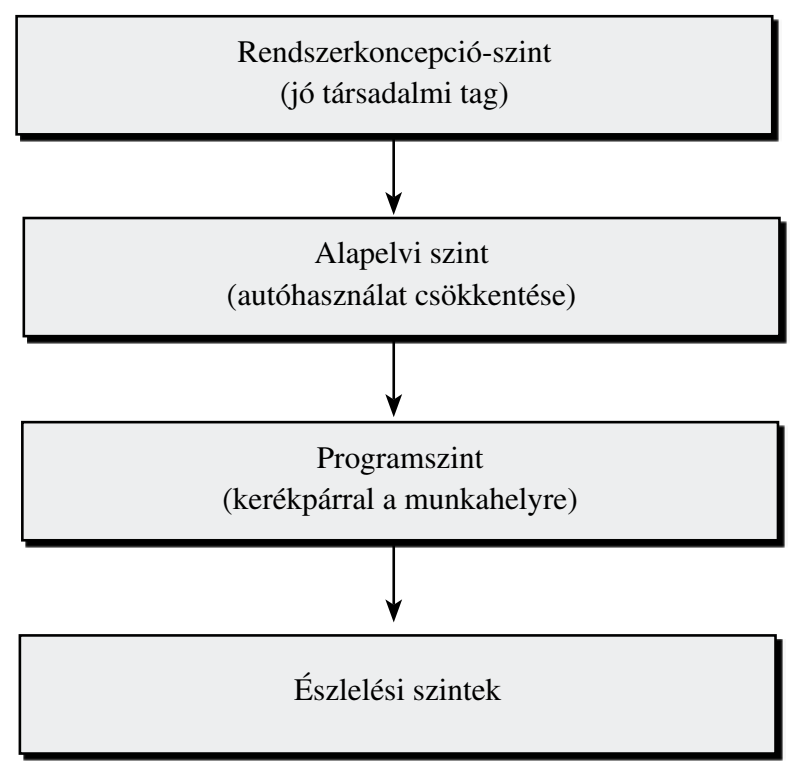

Forrás: Gärling (2002)

A 2. ábra a gépkocsi használatának csökkentésére szolgáló lehetséges referenciaértékeket vagy -célokat mutatja be. A legmagasabb szinten, a rendszerkoncepció szintjén, az embernek saját magáról alkotott ideális képe van, a referenciaérték a „társadalom hasznos tagjának lenni”. Az emberek szeretnék úgy látni magukat, hogy gondolnak a társadalom problémáira, például a környezetrombolásra. A társadalom jó és értékes tagjaként csökkentik az autóhasználatot a környezet védelme érdekében. Ezen a szinten a politikai kezdeményezés lehetséges formája az információs kampány lehet. Ennek pull intézkedésnek kell lennie, mert a push nem nyújt információt az alternatív rendszerkoncepcióról; az csupán arról informálná az embereket, hogy mi az, ami nem elfogadható, és ez csupán a kockázatot ruházná át.

Az autóhasználat csökkentése az alapelvi szint referenciaértéke, mert ez nem egy specifikus magatartási cselekvési terv. A következô szinten (programszint) olyan tervek vannak, mint például a munkába járás kerékpárral, a tömegközlekedés használata esốs napokon, napi bevásárlás esetén gyaloglás. A mobilitásmenedzsment-centrumok vagy utazási tanácsadást végzốk segítik a bejárókat, ingázókat a kevesebb autóhasználatot tartalmazó utazási tervek kialakításában.

A tervezésnek pozitív hatása van a tényleges autóhasználat csökkentésére. Ez a hatás még erôsebb, mint az autóhasználattal kapcsolatos költségek emelkedésének a hatása. Azt is kimutatták, hogy a helyzeti tényezóknek (pl. betegség, időjárás) pozitív és negatív hatása is van az autóhasználatra. Egy régi összefüggés szerint a tudás a motiváció szükséges kiegészítője. A TDM-intézkedések végrehajtásának közösségi információja hatékonyabb, ha használható tudást biztosít, például alternatív közlekedési módokról és indulási idókról. Hasonlóan általános felhívások akkor lehetnek hatékonyak, ha a tevékenységek alternatív folyamatáról információval gyarapodnak.

Magyarországon a „,befolyásolható” autósok aránya az összes személygépkocsi-vezetônek nagyjából háromnegyede (Jászberényi - Pálfalvi, 2006), azaz a rendszerkoncepció szintje viszonylag magas, így az információs kampányok hatásfoka (pl. az autók kitiltása a belvárosból, az útdíjak bevezetése mint push intézkedések) elérhet egy olyan mértéket, ami már érzékelhetô eredményt hoz. Az alapelvi szint referenciaértéke az autóhasználat csökkenése, és amennyiben ez az autósok háromnegyedére kiterjed, akkor az már elég jelentős arány ahhoz, hogy a különféle tervek (kerékpár használata, gyaloglás stb.) realizálódhassanak.

A mobilitásmenedzsment legfóbb célja egy fenntarthatóbb mobilitás elérése oly módon, hogy a közlekedési igények kielégitése során figyelembe veszi a környezetvédelmi, a társadalmi és gazdasági elvárásokat. Az elvek megvalósítása az alábbi konkrét célokon keresztül történik a gyakorlatban: 
- az utazási szokások megváltoztatása a környezetbarát közlekedési módok nagyobb arányú használatának ösztönzésével,

- a felmerülő közlekedési igények kielégítése a már meglévő infrastruktúra hatékonyabb kihasználásával,

- az intermodális kapcsolatok erôsítése,

- a teljes közlekedési rendszer hatékonyságának erôsítése,

- az újabb infrastrukturális beruházások iránti igény csökkentése a meglévő infrastruktúra használatának optimalizálásával.

A mobilitásmenedzsment eszközeinek alapja az információ, a kommunikáció és a promóció, feladata a mobilitási lehetôségekrôl szóló sokrétű információnyújtás, tanácsadás, a közlekedési szokások megváltoztatása, befolyásolása. Mindezek egy új szemléletet próbálnak meg átuiltetni a gyakorlatban mégpedig a tudatos közlekedési szemléletet. A közlekedés fejlesztése a XX. század végéig egyet jelentett az infrastrukturális hálózat bôvítésével, a jármútechnológiák újításaival, az új telematikai rendszerek bevezetésével, az intelligens közlekedési rendszerek mind gyakoribb alkalmazásával. Ezek lényegében a közlekedés fejlesztésének „hard” eszközei.

A környezettudatos magatartás mintájára beszélhetünk a közlekedéstudatosságról, illetve az ahhoz tartozó tartalomról. A közlekedés fejlesztésének „,szoft” módja a fejlesztést egy egészen új szemléletben, a környezetvédelem és a fenntarthatóság szempontjait messzemenôen figyelembe veszi. A közlekedés fejlesztésének e megközelítése nem áll szemben a környezetvédôk álláspontjával, ugyanakkor tagadja, hogy a közlekedés jövője csak egy negatív irányú ,fejlesztés”, egy csökkenô (vagy inkább csökkentett) mértékü kereslet kiszolgálása lenne. Pontosan amiatt, hogy a közlekedésnek nem a mennyiségi paramétereire összpontosít, hanem a meglévő adottságok jobb kihasználását túzi ki célul, a közlekedésfejlesztés fenntartható jellegét támogatja, és csak a szükséges mértékben fogadja el a közlekedési infrastruktúra mennyiségi növekedését.

Amíg a mobilitásmenedzsment inkább a forgalom gerjesztőire: intézményekre, munkahelyekre, rendezvényekre koncentrál, és célja a forgalom hatékony megszervezése, addig a tudatos közlekedés az utazási szokások befolyásolásával, a tudatos magatartás oktatásával, meghonosításával, elmélyítésével foglalkozik.

A legtöbb megoldás a mobilitás, illetve a közlekedés menedzselésére koncentrál. Az intézkedések szinte kizárólag arra irányulnak, hogyan lehet magán a közlekedésen, a közlekedési szolgáltatások minőségén javítani, néhol a forgalom csillapításával, esetenként multimodális rendszerek bevezetésével. A közlekedés oldaláról a következô eljárásokat alkalmazzák:

- az úthálózatok kihasználásának javítása (pl. utazás előtti információk, parkolási információs és javaslati rendszer),

- a tömegközlekedési infrastruktúra fejlesztése (pl. megállók kialakítása, átszállások megkönynyítése),

- a tömegközlekedési információs rendszer javítása vagy a tömegközlekedés elsóbbségének a biztosítása, valamint a tömegközlekedés népszerúsítése,

- multimodális rendszerek bevezetése és fejlesztése: park and ride $(\mathrm{P}+\mathrm{R})$, bike and ride $(\mathrm{B}+\mathrm{R})$,

- új tömegközlekedési módok, szolgáltatások meghonosítása (pl. új módok, integrált tömegközlekedési díjszabás),

- kerékpáros rendszerek fejlesztése (pl. összefüggô hálózat kialakítása, tárolási lehetôségek, lerövidítő kerékpáros hidak),

- az úthálózat tervezésének megváltoztatása (pl. buszsávok kialakítása) stb.

Témánk, a mobilitás mérséklésének a szempontjából fontosabbak azok az intézkedések, amelyek az utazási igények csökkentésére irányulnak, ide sorolhatók a következók:

- az utazási szükséglet mérséklését célzó intézkedések (pl. területfelhasználás tervezése, telekommunikációs intézkedések),

- személygépkocsik behajtásának korlátozása védett területekre (pl. adminisztratív intézkedések, parkolóhelyek csökkentése a belvárosokban, parkolási feltételek szigorítása),

- magántulajdonú jármúvek általános költségeinek a növelése (pl. úthasználati díjak),

- a megközelítési lehetőségek változtatása a gyalogosok javára (sétálóövezetek növelése, játszóutcák létesítése).

Mivel a közlekedés összefüggô rendszer, ezeknek az intézkedéseknek egymással és a városfejlesztési elképzelésekkel, tervekkel összhangban kell lenniük. Akkor célszerú megnehezíteni az autóval való behajtást a belvárosba, ha van megfelelően kiépített parkolóhely a tömegközlekedési eszközök végállomásain, és ha a tömegközlekedés ütemes, kényelmes és nem zsúfolt, mert ellenkezô esetben csak bosszúságot okoz és elkedvetleníti az utasokat. Amennyiben a mozgásigényt csökkenteni szeretnénk, akkor részletes, mindenre kiterjedő felmérés is szükséges 
annak megállapítására, hogy mi váltja ki a nagyfokú mobilitást, hogy helyezhetók el a célpontok annak érdekében, hogy a helyváltoztatás minél rövidebb távolságra irányuljon.

Nem lehet eléggé hangsúlyozni, hogy a közlekedési módokat nem lehet önmagukban, egymástól elszakítva „kezelni”, ráadásul még a közlekedésen belül kialakított összhangot is illeszteni célszerú a területfejlesztési, várospolitikai intézkedésekhez, pontosabban a sorrend éppen fordított: először magát a közlekedést célszerû a területfejlesztéshez illeszteni, majd a különféle közlekedési módok közötti optimális együttmúködést kialakítani. Elsô lépésben az egyéni közlekedés ugrásszerú fejlődésének „megzabolázásához” egy versenyképes tömegközlekedési alternatívát célszerú azzal szembeállítani. Ez elsősorban korszerú, fejlett tömegközlekedést jelent. Amennyiben ez már létrejött, akkor alkalmazhatók a mobilitást csökkentố intézkedések, mint például a torlódási díj bevezetése. ${ }^{1}$

Ezen az állásponton vannak a londoni Economist Intelligence Unit szakemberei (Magazine for Traffic Management and Urban Mobility, 2006), és ezt a véleményt osztja számos hazai szakember is (Berényi, 2004). Kelet-Európában alaposan meg kell vizsgálni a torlódási díj bevezetésének feltételei adottak-e. Ha az infrastruktúra hálózatának kiépítettségében olyan hiányosságok mutatkoznak, amelyek nem teszik lehetôvé a kérdéses útszakasz elkerülését, a tömegközlekedés nem mutatkozik vonzónak, a torlódási díj bevezetését megelózően az alternatív lehetôségek kialakítása szükséges. Budapesten például a belváros zsúfoltsága nem kis mértékben az átmenő forgalomból ered, tehát az M0-s körgyứrú befejezése is enyhítene a torlódáson (mint közlekedésszervezési megoldás), és enyhítene egy összefüggố parkolási rendszer kialakítása is. Ezenfelül a társadalmat is meg kellene gyốzni a környezetkímélő megoldások szükségességéról és előnyeiról. Mindezek ellenére a londoni szakemberek azon a véleményen vannak, hogy ez a térség sem kerülheti el legzsúfoltabb városaiban a torlódási díjak bevezetését.

\section{Mobilitásmenedzsment a fenntartható mobilitás szolgálatában}

A mobilitás növekedése tehát - legalábbis elméleti oldalról - „megzabolázhatónak” túnik, hiszen a jármúvezetốk többsége hajlik a környezet- és közlekedéstudatos viselkedésre, az alternatív közlekedési módok fejlesztése pedig lehetôséget ad a választásra. Mindehhez azonban olyan - az érintettek viselkedését befolyásoló - módszerek, eljárások, tervek szükségesek, amelyek hozzájárulnak a „határtalan” mozgási igények csökken- téséhez, a mobilitás felső határértékeinek kialakításához. A közlekedés keresletszabályozásában a jövoóbeni kutatás célja az, hogy elmozduljanak a járműmozgásoktól a személyek mozgása felé, és befolyásolják az utazási keresletet. A keresletszabályozás mellett fontosak még a mobilitás menedzselésének jogi, technikai keretei, az utazási információk, a fogalomirányítás és a (talán nem távoli) jövőben új technológiák bevezetése.

A keresletszabályozási módszerek közé a következók sorolhatóak (Euroforum, 2007):

- összehasonlítható értékelési módszerek kifejlesztése a szigorú és az enyhe szabályozások terén,

- az innovatív keresletszabályozási stratégiák, a légszennyezésról, a zajról és a forgalmi torlódásról szóló új mobilitásszabályozási irányelvek következményeinek kiértékelése,

- az új mobilitási viselkedésmódok marketingkutatása,

- a környezeti zónáktól, jármútípusoktól vagy a forgalmi, torlódási helyzettől függóen változtatható díjak kidolgozási lehetôségének kiértékelése.

A keresletszabályozáshoz az alábbi jogi és technikai keretek szükségesek:

- technikai standardok kidolgozása: jegyértékesítés, információ koordinálása, díjfelszámítási rendszerek, múholdas helymeghatározó alkalmazások,

- a rendszerek és az irányelvek együttmúködtethetősége.

Az elóbbieknél lényegesen tágabb a forgalmi és utazási információk, valamint a forgalomirányítás kérdésköre:

- koordinált útvonal-tervezési és tájékoztatási elméletek (minden közlekedési módban),

- a kerékpározási és a gyaloglási feltételek fejlesztése javított információ és irányítás által - a tömegközlekedéshez stb. hasonlóan,

- általános sebességszabályozási rendszerek bevezetése,

- a forgalom és az utazási információk biztosítása: átfogó utazási információk az utazás előtt és alatt, amelyek javítják az utazási idő meghatározhatóságát,

- fejlett forgalomirányítási modellek, ideértve a forgalmi, torlódási, hálózat-túlterheltségi modelleket, amelyek a hálózaton bonyolított teherforgalom sajátosságait integrálják,

- a forgalmi torlódásokra és a környezeti helyzetre vonatkozó adatgyújtések javítása, például múholdas helymeghatározó, RFID (RFID Radio 
Frequency Identification - Rádió Hullámhossz Azonosító), segítő rendszerek stb. használata,

- intelligens és dinamikus hálózatirányítási rendszerek.

Ami az új jármúvekre és szolgáltatásokra kifejlesztendố technológiákat, valamint az emberek dinamikus jelzóberendezésekre adott reakcióját illeti, ezekhez elengedhetetlen.

- az ember-gép interfészen végzett kutatás: mi az emberi reakció egy adott mennyiségú információ esetén? Mi a hatása a forgalombiztonságra, ha az információt útközben adják?

- automatizált jármúvek és ezek integrációja a tömegközlekedési és a teljes közlekedési rendszerbe.

A felsorolt megoldások egy része már nem teljesen új, hiszen tapasztalatok is összegyuultek már akár a keresletszabályozás, akár a hálózatirányítás területén. A jelenlegi keresletszabályozási stratégiák a legjobb gyakorlatokra épülnek, azzal a céllal, hogy irányítsák a városi közlekedés keresletét, és számos új kezdeményezést is tartalmaznak (Euroforum, 2007).

Vannak már problémamentes mobilitási szolgáltatások, mint például a városba beutazás megosztása (lift sharing), közhasználatú kerékpárok (pl. Bécsben, Párizsban és a legújabb tervek szerint hamarosan Londonban is), „Hívj-egy-buszt!” szolgáltatások (NICHES Projekt). Az is ismeretes, hogy az optimalizált tömegközlekedést többen használják. A forgalom csökkentése érdekében számos uniós nagyvárosban alacsony károsanyag-kibocsátási zónákat alakítottak ki. Helyi adók és díjak használhatók a közlekedés korlátozására, és emellett korlátozható a városok bizonyos zónáiba való belépés is (pl. torlódási díj). A parkolás szabályozása is nagyon fontos eszköz. Végül, de nem utolsósorban az uniós kutatások alapján - a legjobb gyakorlatokat tanulmányozva és elemezve (Extr@Web) - meghatározhatók a száz- és ötszázezer fó közötti lakossal rendelkező városokban és városi területeken végzett, csúcsminőségú tömegközlekedés kritériumai az optimális tömegközlekedési hálózatok tervezésére és megszerkesztésére.

A hálózatirányítás esetében az a megállapítás született, hogy a közlekedési és a tömegközlekedési hálózat teljes egészének irányítása és szervezése erôsen függ az integráció szintjétől és a helyi szervezetek és intézmények szerkezetétól. Számos uniós városban létrehozták a tömegközlekedést múködtető́k és az infrastruktúrával foglalkozó menedzserek integrált és több közlekedési módot magába foglaló (multimodális) utas információs rendszerét. Sok európai városban megta- lálható az integrált jegyértékesítés a tömegközlekedést múködtetốk, a parkolóhely és a távolsági vonatközlekedést üzemeltető́k és általánosságban minden kapcsolódó résztvevô között. A mobilitásmenedzsmentet segíti a rendszerelvek harmonizálása az automatizálás különbözô fokain lévô városi vasút által irányított átszállási rendszereknél, az indító vezérlő használata a menetrend szerinti tömegközlekedési eszközöknél, lehetôség szerint buszos gyors átszállási rendszerekkel párosítva.

A közlekedés keresletszabályozásában a jövốbeni kutatás célja az, hogy elmozduljanak a jármúmozgásoktól a személyek mozgása felé, és hogy befolyásolják az utazási keresletet. A városi és elôvárosi közlekedésben, a mobilitás szabályozásában egyre inkább előtérbe kerülnek az integrált és összehangolt szolgáltatások. A felhasználók és a közlekedést fizikailag szolgáltatók közötti (jármúuizemeltetés és infrastruktúra) dinamikus kölcsönhatás lehetôvé teszi, hogy a szolgáltatásokat jobban hozzáigazítsák az adott felhasználói csoportokhoz, valamint a tömegközlekedés és az egyéni városi közlekedés racionálisabb, hatékonyabb kiaknázását támogassák. A szolgáltatások különbözô városi közlekedési formákat integrálnak, és az egyes közlekedési szolgáltatóktól vagy az egyes közlekedési formáktól függetlenül, külön-külön is múködtethetők. Ezen szolgáltatások alapja a valós idejú, operációirányítási adatok rendelkezésre állása. Fố területei közé tartoznak: az utastájékoztatás, az elektronikus jegyértékesítés és a marketingstratégiák.

\section{Utasinformáció}

A legfontosabb talán a valós idejú, személyre szabott és integrált, a számítástechnikán alapuló utastájékoztatás. Az indulás elő́tt ajtótól ajtóig tervezô internetes eszközöket egyéni gépjármú-közlekedéshez és tömegközlekedéshez is széles körben használnak, és ezek, egyre többször, valós idejű forgalmi szituációk adatain alapulnak. A gépkocsikban lévő navigációs rendszerek már többé-kevésbé alapfelszereléssé váltak. A tömegközlekedést használók egyre többször élvezik a peronokon, a megállókban és a jármúveken a valós idejú információt közvetítő kijelzók elônyeit (Euroforum, 2007). A kutatások során vizsgálták az utazási viselkedést, az internetalapú tömegközlekedési útvonaltervezók elfogadottságát és alkalmazásukat. Ezek különböző közlekedési szolgáltatásokat ötvöznek, beleértve a gépkocsimegosztás (car sharing), a taxi- és a parkolási információkat és tanácsadást, a gépkocsimegosztás elektronikus helyfoglalási rendszerét, a tömegközlekedés és az útdíjak elektronikus jegyértékesítését. 
A különbözô típusú utasinformációk hatásairól - az utazási viselkedésekben - kevés az ismeretünk. Néhány kutatás jelezte, hogy a személygépkocsi-használat 10\%kal visszaesett az integrált tömegközlekedési útvonaltervezók bevezetését követóen. Fontos, hogy az egyes utakat kisebb utak láncolatának tekintsük. Számos közlekedési forma használható ebben a láncolatban. Emiatt oda kell figyelni - a különleges tömegközlekedési szolgáltatások mellett - a gyalogosok, a kerékpárosok és a személygépkocsit használók (azok, akik az utazás csak egy részén használják gépkocsijukat) részére nyújtott szolgáltatásokra. Ez szükséges ahhoz, hogy a városi közlekedés intermodálisan (több közlekedési formát kombinálva) használhatóbbá váljon.

\section{Elektronikus jegyértékesítés}

Számos különféle elektronikus jegyértékesítéssel és viteldíj-menedzseléssel rendelkezố uniós országban tömegközlekedési projektek és újítások találhatók: érintésmentes, okos kártyák, papírjegyek elektronikus cshippel (papíralapú csipkártyák), check-in, check-out rendszerek (az utazás megkezdése előtt és az utazás befejezése után is jegyet kell kezelni), nagy távolságú technológiai eljárások stb. A mobiltelefon általi jegyértékesítés korszerúnek minősíthető, de használata bizonyos felhasználói csoportokra korlátozódik. Olyan megoldás is található, ahol ezeket más szolgáltatásokkal, például parkolási díjjal vagy múzeumi belépóvel együtt értékesítik. Az információs és az operációirányítási rendszerek integrálódása még fejletlen. Az elektronikus jegyértékesítés példa nélküli lehetôségeket kínál az árak differenciálására (Euroforum, 2007).

\section{Marketingstratégiák}

A marketingstratégia használata még mindig eléggé új jelenség a tömegközlekedési, közösségi közlekedési szektorban. Szélesebb körú elterjesztéséhez szükséges áttérni a kínálatorientált irányításról a keresletorientált irányításra. A személyre szabott tájékoztatás és jegyértékesítési szolgáltatás hatékony marketingeszköz lehet. Ebben a tekintetben az ITS (Intelligent Transport System - intelligens közlekedési rendszer) lehet a tömegközlekedési szektor újításainak katalizátora.

A városi közlekedésben a mobilitásmenedzsmentet a technikai újítások gyors növekedése jellemzi. Gyakran a kutatási eredmények elévülnek a tényleges fejlődéshez képest. Ennek ellenére, amikor a technikai újítások kiforrottá válnak, akkor kezdjük megérteni, milyen keveset tudunk a rendszerek használatáról és arról, hogy ezek hogyan befolyásolják a felhasználói viselkedést és a közlekedési szektor szervezetét. Látható, hogy a kü- lön zajló fejlesztések egyre inkább személyekre szabott szolgáltatási területre integrálódnak. Ugyanazokat az alapadatokat felhasználva egységesítik az azonos felhasználói csoportokat megcélzó utazási információkat, elektronikus jegyértékesítést és marketinget, kialakítva így egy integrált üzleti lehetőséget.

\section{Mobilitásmenedzsment az Európai Unióban}

A személygépkocsi nem, vagy korlátozottan képes a városi közlekedési igények kielégítésére. Az infrastruktúra „mennyiségi” mutatói alapján a kelet-európai városok lemaradása kimutatható, de nem jelentős, Budapesten az infrastruktúrának a kerékpárút a legjobban elmaradott eleme.

Az egy foóre jutó GDP alapján Koppenhága és Rotterdam a leggazdagabb városok közé tartozik, de ezer lakosra vetítve a gépkocsi-ellátottság a dán fővárosban mindössze 208, Rotterdamban is csak 300 . Budapesten a bejegyzett gépkocsik száma 2006-ban meghaladta a 600 ezer darabot, az 1990-es évek közepe óta közel 8\%-kal emelkedett, miközben a lakosság 12\%-kal csökkent, így az ezer lakosra jutó gépkocsik száma meghaladta a 360 darabot, ugyanezen idő alatt a tömegközlekedés iránti igény erősen csökkent. Mindezt tovább tetézik a szuburbanizációs tendenciák negatív hatásai (Erhart, 2007).

A forgalom, a forgalmi sürúség növekedése együtt jár a közúti forgalom folyamatos lassulásával és természetesen a környezetterhelés növekedésével. A sebességcsökkenés a legnagyobb mértékú a belvárosi kerületekben, 1998-ról 2003-ra 40\%-kal csökkent a sebesség, az átlagsebesség már nem éri el a 13 km/órát (Erhart, 2007).

Abban a legtöbb közlekedési szakember és közlekedéspolitikus egyetért, hogy a jelenlegi zsúfoltságot meg kell szüntetni, a megoldáshoz vezető lépések, eljárások azonban különbözőek. A városba való behajtásért ún. torlódási díjat szednek Szingapúrban, Bergenben, Oslóban és Trondheimben, valamint Londonban és Stockholmban, és számos európai nagyváros tervezi annak bevezetését. A városi úthasználati díj szedése jó eszköze a forgalmi torlódások csökkentésének, ha a bevezetésnek megvannak az infrastrukturális feltételei $(\mathrm{P}+\mathrm{R}$, $\mathrm{B}+\mathrm{R}$, megfelelóen sứú közlekedési hálózat, vonzó tömegközlekedés stb.).

Az Európai Unióban közlekedési rendszergazdálkodás (Transportation Sytem Management) folyik, ennek keretében optimalizálják a mobilitási feltételeket, szem elótt tartva a rendelkezésre álló források (pénzügy, energia) korlátozott voltát, a környezetkímélés kötelezettségét, valamint a forgalombiztonság 
követelményeit. A közlekedési rendszer résztvevôit (személygépkocsi, közösségi közlekedési eszközök, gyalogosok, kerékpárosok stb.), mint a teljes rendszer elemeit, olyan módon kellene koordinálni, hogy ezáltal az egész rendszerre vonatkozó maximális hatékonyság és gazdaságosság elérhető legyen (közlekedési igény, közlekedési kínálat befolyásolása).

Az Európai Bizottság városi közlekedésról kiadott Zöld Könyve (2007) megállapítja, Európa városai és nagyvárosai nem hasonlítanak egymásra, de azonos problémákkal küzdenek, és közös megoldást keresnek. A városi mobilitással kapcsolatos politikák csak abban az esetben lehetnek hatékonyak, ha a lehetố legintegráltabb megközelítést alkalmazzák, kombinálva tehát minden egyes probléma esetében a leghelytállóbb válaszokat: múszaki innováció, a tiszta, biztonságos és intelligens közlekedési módok fejlesztése, gazdasági ösztönzés vagy jogszabályi módosítások.

A városi és nagyvárosi környezetben a közlekedési dugók jelensége az egyik legégetóbb probléma, bár nincs egyedüli megoldás a közlekedési dugók csökkentésére. A személyautó használatát kiváltó lehetôségeket, a gyaloglást, a kerékpározást, a tömegközlekedést, a motorkerékpár és a robogó használatát vonzóvá és biztonságossá kell tenni. Lehetôvé kell tenni, hogy a polgárok a különböző közlekedési módok közötti hatékony kapcsolatok révén optimálisan szervezhessék meg közlekedésüket. A hatóságok feladata a kombinált közlekedési módok használatának bátorítása és a dugókat mérséklő intézkedések nyomán felszabaduló helyek újraelosztása. Az intelligens és a helyi igényekhez alkalmazkodó közlekedésirányítási rendszerek is bebizonyították, hogy alkalmazásukkal hatékonyan lehet csökkenteni a dugókat.

A Zöld Könyv (2007) javaslatai közé tartozik a gyalogosközlekedés és a kerékpározás népszerüsité$s e$. A gyaloglás és a kerékpározás vonzóbbá tétele és biztonságának fokozása érdekében a helyi és regionális hatóságoknak gondoskodniuk kell arról, hogy ezek a közlekedési módok teljes körúen beépüljenek a városi mobilitással kapcsolatos politikák fejlesztésébe és nyomon követésébe. Nagyobb figyelmet kell szentelni a megfelelő infrastruktúra kifejlesztésének. A személyautók használatának optimalizálása kiterjed a car-poolingra, a parkolási politika felülvizsgálatára és átalakítására (pl. differenciált díjak: ingyenes a város szélén és magas a belvárosban). A mobilitásirányítás kiegészíti a hagyományos, infrastruktúraalapú intézkedéseket azzal, hogy még kialakulásuk előtt befolyásolja a közlekedési szokásokat, és igyekszik az emberek figyelmét felhívni a fenntarthatóbb közlekedési módokra. Például az infrastruktúra-fejlesztóket arra lehetne bátorítani, hogy készítsenek területspecifikus mobilitási tervet a tervezési engedély megszerzésére irányuló eljárás részeként.

Járható útnak látszik a zöld közbeszerzés támogatása is. Mit is jelent ez a kifejezés? Az EU városi közlekedési Zöld Könyve szerint lehetséges megközelítésként felmerülhet a külsố költségek internalizálása, azaz ha az odaítélési szempontok között a jármú ára mellett szerepelnek a beszerzés tárgyát képezó jármú egész életciklusára a múködtetéshez kapcsolódóan megállapított, az energiafelhasználásból, a szén-dioxid-kibocsátásból és a szennyezóanyag-kibocsátásból eredô költségek. Ha a jármú egész életciklusára megállapított költségeket belefoglalják a közbeszerzéssel kapcsolatos döntési szempontok közé, nőhet a múködtetési költségekkel kapcsolatos tudatosság. Ez versenyelőnyhöz juttatná a legkevésbé környezetszennyező és a leginkább energiahatékony jármúveket, és emellett csökkentené az összköltségeket. A közszféra így a „fenntartható gazdaság” tekintetében példát mutathat a piaci szereplóknek.

Megoldást jelenthet a közlekedési korlátozások és városi útdíjak bevezetése. Bár az eddig elszigeteltnek tekinthetô megoldások jól érzékelhetó pozitív eredményeket hoztak, de egyelóre együtt járnak azzal is, hogy új ,határvonalakat” képezve széttagolt városi területek kialakulásához vezetnek.

Az intelligens közlekedési rendszerek alkalmazása egy újabb eszköz az egyéni közlekedési teljesítmények visszaszorítására. A közlekedéssel és az utazással kapcsolatos adatok feldolgozása információt és segítséget nyújt az utasoknak, a jármúvezetốknek, a szolgáltatóknak és a hálózatirányítóknak, lehetővé teszi a közlekedés dinamikus ellenôrzését. Számos eljárás már ma is hozzáférhetố a közúti, vasúti vagy vízi közlekedés számára. Az Európai Bizottság reményei szerint az elkövetkezendố években ezeket az alkalmazásokat - pontosabb helymeghatározással - a Galileo múholdrendszer még továbbfejleszti (az eddigi tapasztalatok nem igazolják ezt az optimizmust).

Az Európai Bizottság úgy véli (Zöld Könyv, 2007), hogy az elóbb felsorolt megoldások - mint az integrált tervezési folyamat elemei - a városi, elôvárosi közösségi közlekedés támogatásával, az intelligens közlekedési rendszerek széles körú alkalmazásával, rugalmas és innovatív közlekedési szolgáltatásokkal, biztonságosabb közlekedéssel és környezetkíméló jármúvekkel képesek létrehozni a polgárok igényeinek megfelelő kollektív közlekedést. Vonzó és az egyéni közlekedéshez közel álló színvonalú közösségi közlekedés nélkül a személygépkocsi-közlekedés térhódítása nem állítható meg. A különféle intézkedések hierarchiája, illetve összefüggései a 3. ábrán láthatók. 


\section{Az integrált tervezési folyamat különböző szintjei}

\section{Településfejlesztés és területhasználat}

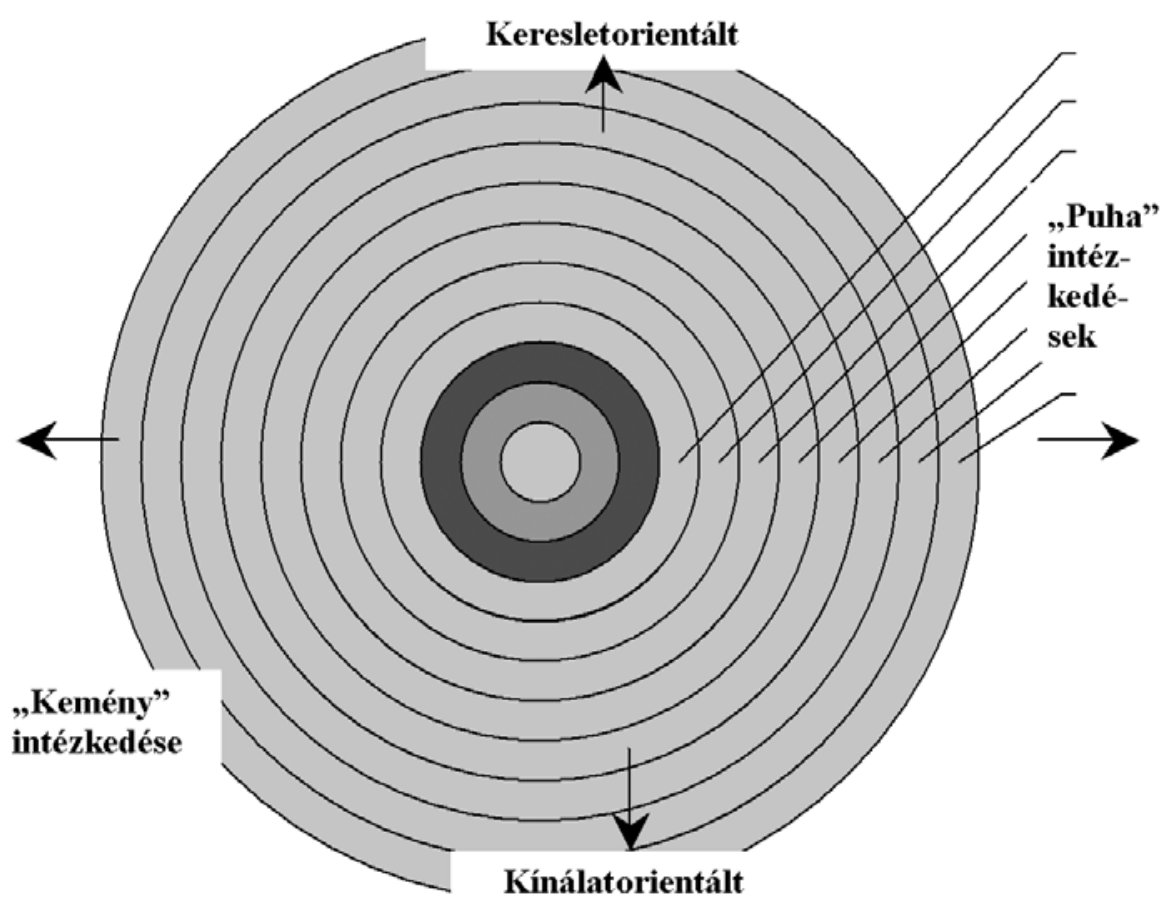

Forrás: ECTRI (2007), p. 7.

\section{Mobilitási menedzsment nyomai és lehetôségei a budapesti agglomerációban}

A budapesti agglomerációban az elózőekben felsorolt megoldások közül alig néhányat találunk, a helyzetet inkább a hiány, mint az előremutató megoldások jellemzik. Pozitív példaként említhetô meg a BudapestVác-Szob vasútvonalon az ütemes menetrend bevezetése, amelynek következtében az eljutási idő jelentôsen csökkent, és az a korábbi közúti forgalom egy részét az elôvárosi vasúti közlekedésre terelte. Az ütemes menetrend bevezetése a szobi-veresegyházi vonalon 8-10\%-os többlet-utasforgalmat generált. Ezek a vasútvonalak jellegzetesen elővárosi forgalmat bonyolítanak le, a teherforgalom elhanyagolható mértékú (Pápay et al., 2005). Ez már az ún. best practice, és ezt lenne érdemes folytatni a többi keleti, nyugati és déli irányú elővárosi forgalmat lebonyolító vasútvonalon is. Ennek megvalósításában nagy szerepük van a 2007-ben, a Közlekedéstudományi Intézet keretén belül létrehozott regionális közlekedési irodáknak.

A szentendrei HÉV például elôvárosi forgalmat is lebonyolít. A Pomáz és Pannónia telep közötti szakaszt kivéve beépített területen halad, a HÉV üzemmód nincs összhangban a beépített környezettel, kettévágja a vá-
4. ábra rosrészeket. A gödöllói és a ráckevei HÉV vonalvezetése ennél kedvezóbb. Ezek mielőbbi fejlesztése, és esetleg a csepeli és szentendrei HÉV összekötése (a belvároson belül alagútban haladna, mint az RER Párizsban) is részben hozzájárulhatna, ha a mobilitás csökkentéséhez nem is, de a személygépkocsi-közlekedés növekedési ütemének mérsékléséhez igen.

A jövoóbeni célok közé tartozik a kötött pályás törzshálózat létrehozása (Pekli et al., 2006), a kapcsolódási pontok fejlesztése és az ún. eszközváltó zónák kialakítása a városhatáron kívül, hiszen Budán és Pesten egyaránt a városba vezetô utak városhatár-térségi bevezetố szakaszai alkotják 2008-ban is a legszúkebb keresztmetszetet.

A Volánbusz ugyanazokat a közutakat és azokon belül ugyanazokat a sávokat használja, így az eljutási idő szempontjából nagy előnyt a személygépkocsi-közlekedéssel szemben csak a viteldíjban képes nyújtani. Csúcsforgalmi idôszakban a járatok egyik irányban vannak kihasználva, a másik irányban többnyire üresen közlekednek. Bár hálózata lényegesen súrúbb, mint a kötött pályás közlekedésé, a járatok növelése csak parciális hatást gyakorolna a személygépkocsi-forgalom módosulására.

A magyarországi közlekedési infrastruktúra hálózatát a kiépítetlen elemek hiánya jellemzi. A Magyar Közlekedéspolitikai Koncepció (GKM, 2003) is részben ezeknek az elemeknek a kiépítését szorgalmazza, és a fó prioritások szintjére emeli. Ehhez hozzá kell tenni, hogy a közúti kapcsolatok növelése mellett (bár a koncepcióban nincs nevesítve) ide értendő a kerékpárút-hálózat növelése, a $\mathrm{P}+\mathrm{R}$ és $\mathrm{B}+\mathrm{R}$ rendszer mielóbbi kialakítása.

\section{Forgalomszabályozás és parkolás}

A forgalomszabályozás célja:

- adott jellemzókkel rendelkezó utakon a viszonylag legelönyösebb forgalmi körülmények, a legjobb forgalomminőség elérésének elősegítése,

- a viszonylag legnagyobb forgalombiztonság forgalomtechnikai előfeltételeinek megteremtése,

- a meglévő közlekedési létesítmények, pályák kedvezóbb kihasználása. 
Mondhatni, hogy a budapesti agglomeráció $\mathrm{P}+\mathrm{R}$ rendszere kritikán aluli. A Budapestról kiinduló utazások 1,0\%-a, a környékról kiinduló utazások 1,5\%-a használja a P+R rendszert (Pápay et al., 2005). A befogadóképességet, számukat mindenképpen növelni kell, különösen a kötött pályás közlekedési módok - beleértve az elővárosi vonalakat is - végállomásai közelében! Valójában $\mathrm{P}+\mathrm{R}$ rendszerról a budapesti agglomerációban nem is beszélhetünk, hiszen annak csak elemei vannak meg.

A forgalomcsillapítás célja a városi területek, elsôsorban a városközpontok és lakóterületek környezetminôségének, az ott élốk életminőségének javítása. Ennek érdekében a forgalomcsillapított területekról kitiltják az átmenố forgalmat a kiinduló és célforgalom, valamint a területen belüli forgalom számára. A gyalogos és kerékpáros közlekedôk biztonságát növelő intézkedések bevezetésével a környezetbarát közlekedést preferálják a gépjármú-közlekedéssel szemben.

A forgalom szabályozását egyértelmúvé teszik és egyszerüsítik, fizikai eszközök telepítésével akadályozzák meg, hogy a jármúvek az előírtnál nagyobb sebességgel közlekedjenek. A szabályozás hatására csökken az átlagsebesség, változik a vezetôi magatartás, növekszik a forgalom biztonsága, a balesetek gyakorisága csökken, javulnak a környezeti feltételek, valamint a gyalogos- és kerékpáros közlekedés körülményei. Mindezek együttes hatására az övezet környezetminősége, lakosságának életminősége javul (Pápay et al., 2005).

\section{Összefoglalás}

A mobilitásmenedzsment eszközeinek alapja az információ, a kommunikáció és a promóció, feladata a mobilitási lehetốségekról szóló sokrétú információnyújtás, tanácsadás, a közlekedési szokások megváltoztatása, befolyásolása. Mindezek egy új szemléletet próbálnak meg átültetni a gyakorlatban mégpedig a tudatos közlekedési szemléletet. A közlekedés fejlesztése a XX. század végéig egyet jelentett az infrastrukturális hálózat bővítésével, a jármútechnológiák újításaival, az új telematikai rendszerek bevezetésével, az intelligens közlekedési rendszerek egyre gyakoribb alkalmazásával. Ezek lényegében a közlekedés fejlesztésének „hard” eszközei.

A környezettudatos magatartás mintájára beszélhetünk a közlekedéstudatosságról, illetve az ahhoz tartozó tartalomról. A közlekedésfejlesztés „soft” módja a fejlesztést egy egészen új szemléletben, a környezetvédelem és a fenntarthatóság szempontjainak messzemenó figyelembevételével végzi. A közlekedés fejlesztésének e megközelítése nem áll szemben a környezetvédók álláspontjával, ugyanakkor tagadja, hogy a közlekedés jövője csak egy negatív irányú „,fejlesztés”, egy csökkenô (vagy inkább csökkentett) mértékú kereslet kiszolgálása lenne. Pontosan amiatt, hogy a közlekedésnek nem a mennyiségi paramétereire összpontosít, hanem a meglévő adottságok jobb kihasználását túzi ki célul, a közlekedésfejlesztés fenntartható jellegét támogatja, és csak korlátozott mértékü közlekedési infrastruktúrafejlesztést fogad el.

\section{Lábjegyzet}

${ }^{1}$ E helyütt figyelmen kívül hagyom azokat a szélsôséges elméleteket, amelyek nem veszik figyelembe a komplexitást, és az adott jelenség egyetlen oldalát ragadják meg.

\section{Felhasznált irodalom}

Axhausen, K. - Garling, T. (1992): Activity-based approaches to travel analysis: conceptual frameworks, models, and research problems. Transport Reviews. 12.

Economist Inteligence Unit (2006): Road pricing preferred solution to traffic congestion in Central European cities. Magazine for Traffic Management and Urban Mobility. 11.

ECTRI (2007): ECTRI's contribution to the European Comission Green Paper on Urban Transport. INREST 2007. 04. 18.

Erchart Sz. (2007): A budapesti közlekedési dugók okai és következményei. Közgazdasági Szemle, május

Euroforum (European Research Forum for Urban Mobility) (2007)

Európai Bizottság (2007): Zöld Könyv: A városi mobilitás kultúrája felé. Brüsszel

Garling, $T$ (2002): A conceptual analysis of impact of travel demand management on private car use. Transport Policy. 11.

Jászberényi M. - Pálfalvi J. (2006): Közlekedés a gazdaságban. Aula Kiadó, Budapest.

Pápay Zs. et al. (2005): Dunakanyar térség fenntartható közlekedése. Munkaanyag. Közlekedés Fóvárosi Tervezô Iroda Kft. 2005. október

Pekli F. et. al (2006): Budapest agglomeráció közlekedésfejlesztési kiemelt program II. fázisú eredmény dokumentációja. Budapest 2006. február- augusztus

Steg, L. - Vleg, C. (1997): The role of problem awareness in willingness-to-change car use and in evaluating relevant policy measures. Traffic and Transport Psychology. Pergamon Press, Oxford

Vlek, C. - Michon, J. (1992): Why we should and how we could decrease the use of motor vechicles in the future. IATSS Research 15.

Cikk beérkezett: 2008. 2. hó

Lektori vélemény alapján átdolgozva: 2008. 4. hó 